\title{
AN EMPIRICAL ANALYSIS ON LEVEL OF E-BUSINESS APPLICATION IN PORTS OF NAUTICAL TOURISM IN MONTENEGRO
}

\author{
Nikola Vukčević1 , Marijana Ljubić \\ ${ }^{1}$ Maritime Faculty Bar, Šetalište Kralja Nikole Potkovica D1, 85000 Bar, Montenegro \\ ${ }^{2}$ Graduate School of Business Studies, Goce Delčeva 8, 11070 Novi Beograd, Serbia
}

Received 5 July 2016; accepted 25 August 2016

\begin{abstract}
Electronic business in tourism industry plays an essential role in increasing the level of competitiveness in a global, highly competitive tourism market. Therefore, the main objective of this paper is to analyze and determine the level of electronic business application in different organizational sectors, among selected ports of nautical tourism in Montenegro. The research is based on data gathered from 150 marina managers through a structured questionnaire. This study included five largest Montenegrin marinas, where three of them are state-owned, while other two are privately owned. This implies a different ownership arrangement, management system and business organization. Analysis results of these different business systems, which perform the same activity, can create a clearer idea of the business organization, investment and achieving economic effects of modern business and the influence that they have on the further development of the yachting industry. The survey was conducted from January to April 2016. The findings suggest that the level of e-business application within Montenegrin marinas is far from desirable. Further analysis has revealed that the main reasons for low level of e-business adoption among ports of nautical tourism in Montenegro are the lack of clear e-business strategy, low level of ICT investments and knowledge among managers. However, the findings contain important recommendations for marina's managers and owners about the potential gains of accepting/using e-business for their businesses and their effects on business performance. Results presented in the study can also provide useful insights for government agencies such as Montenegrin Ministry of Transport and Montenegrin Ministry of Sustainable Development and Tourism, for the formulation of their future strategies and legal frameworks regarding nautical tourism and shipping.
\end{abstract}

Keywords: e-business, electronic business, ports, yachting industry, yachting, marinas.

\section{Introduction}

Among the most important factors influencing the globalization of the world economy are international tourism and intensive use of the Internet and e-business technologies. Tourism in Montenegro is one of the most important economic activities with biggest potential for economic growth and development, which has different multiplicative effects. According to official statistical data, revenues from tourism in

\footnotetext{
${ }^{1}$ Corresponding author: nikolafms@gmail.com
} 
Montenegro, for 2015 amounts to over 800 million Euros, an increase of about $10 \%$ compared to year 2014 (Montenegrin Ministry of Finance, 2015). The main reasons for transition to the development of elite tourism in Montenegro are shown within changed tourism development strategy and according to the main strategic goal of tourism development in Montenegro until 2020 (Ministry of Tourism and Environment of Montenegro, 2008).

On the other hand, according to Internet Live Statistics, only $62 \%$ of the total population of Montenegro is on-line, an increase of $0,9 \%$ in respect to 2015 (Internet Live Statistics, 2016). In other words, Montenegro, in Internet world county rankings, is on $147^{\text {th }}$ place after Slovenia, Albania, Croatia and Serbia. Main reasons for such low ranking place according to Global IT Report are: almost non-existent intensity of local competition, poor firm-level technology absorption, extent of staff training and among other things impact of ICTs on new organizational models (World Economic Forum Report, 2015). Another report on development perspectives of IT sector in Montenegro point out key reasons for nonuse of Internet: the lack of unique digital literacy, high prices of Internet access, costly IT accompanying equipment and the lack of efficient competitiveness at the broadband market (Montenegro Chamber of Commerce, 2015). Internet and ICT represent modern pillars of society development and have undeniable impact on different sectors. Bad economic situation in Montenegro created under the global economic crisis influence affected also the IT market. But, according to title, main objective of this study was to determine the real level of e-business adoption in specific travel and transport sector of nautical tourism.
Nautical tourism is a type of selective tourism and the phenomenon which has been significantly growing and recording high growth rates in the last twenty years (Lukovic, 2007). Yachting and cruising represents its basic forms. Yachting industry is a very complex system composed of a wide variety of nautical - tourist enterprises (Šamanović, 2002). Different other studies identify marinas as the center of the entire yachting industry (Kesar, 2013; Dulčić, 2002). Moreover, yachting industry system, is composed by a number of other operating elements which are directly or indirectly connected with the marinas. Those are different shipping organizations, agencies, freight forwarding, customs duties and other enterprises. All of them are located in various parts of the world. Together they represent very complex structure of the world yachting industry. It is clear that so large number of participants of world yachting industry exchange vast amounts of information on hourly basis, and require a fast, reliable and secure real-time communication solutions. These facts clearly indicate that the yachting industry is a favorable environment for e-business implementation and development. Using Internet and e-business techniques, modern marinas, as centers of world yachting industry, are able to efficiently manage supply and demand, reduce costs of financial transactions, increasing the possibility of entering into new nautical - tourist market and increase the speed of operations and access to important business information. Another reason marinas in yachting industry embraced modern technology of electronic business is to reduce operating costs and retain competitive advantage in the global yachting market (Luković and Šamanović, 2006). Nowadays, modern technologies became an imperative on global yachting market, where all participants operate 
by knowledge economy rules. Former traditional organizational structures do not have the necessary speed and flexibility that is required in order to successfully respond to constant changes in volatile business environment. Traditional hierarchical organizational structure cannot meet the increasing demands of modern customers and users of shipping and port services. Therefore, determining the level of impact of Internet and e-business represent important issue in modern business and contemporary area of research. The paper is organized as follow. After Introduction, in Section 2 we present the literature review of application of e-business in tourism and especially in sectors of nautical tourism.

\section{Literature Review}

When analyzing the level of e-business adoption in the yachting industry, there must be considered the application of e-business in tourism and maritime shipping. Since yachting industry represents a combination of maritime and tourism industry, or their cross-section. If the application of e-business in the yachting is being observed from the shipping viewpoint, there can be noticed numerous attempts in e-business adoption in different maritime transport activities such as: shipping activities, commercial operations, financial transactions, maritime environmental preservation or safety and security. Modern Internet based e-business technologies are being use to create maritime shipping electronic networks or "digital business ecosystems" (Dourmas and Nikitakos, 2009). Moreover, as on-time, full and reliable information represent the basis of international maritime transport, Internet and electronic business can be used to prevent delays and interruptions in information flows (Twrdy and Krmac,
2002). There are many different areas of possible e-business adoption in shipping transport and service companies. From fleet management, loading activities, on-board communication to transport optimization plans (Krmac, 2007). Other authors also agree that main benefits of utilizing e-business adoption in maritime transport are quicker access to information, improved communication with customers and business partners, reduced costs, higher productivity and quality of service (Nikitakos and Lambrou, 2007). Results of many other relevant researches indicate that moving to an electronic way of doing business affects the transformation of previous way of doing business, especially in the part that relates to communication, promotion and production services. Leads to the creation of entirely new products and services, e-business reduces the total cost of business, number of employees and affects the efficient and effective use of available resources. Equally, when observed from tourism perspective, nautical tourism is also very affected by Internet and e-business technologies. The main reasons for that, according to the author Sheldon are because the information represent bloodstream of the tourism industry (Sheldon, 1994). Accordingly, author Wayne states that the effective application of information communication technologies is the basis of tourism future (Wayne, 1995). According to the statements of author Buhalis, the impact of information - communication technologies in the tourism industry is diverse (Buhalis, 1996) while author Hjalager points out that modern technologies encourage product innovation, business processes as well as the management mode (Hjalager, 2010). Most authors argue that due to tourist's behavior and preferences changes, there is growing tourism market segmentation. Nowadays, potential tourists are involved 
in several different segments of the tourism market simultaneously. Modern tourism industry can be viewed as hybrid because it combines large amounts of information with the provision of tourism services. According to this observation, there are calls to imperceptibly integration of information and physical services, with flexible adjustment of both physical IT parts (Werthner and Klein, 1999).

Since the modern nautical tourism business is aimed at tourists as individuals, it requires detailed knowledge of their wishes, needs, demands and wants, which in many authors opinion, is only possible achieving with intensive of ICT and e-business application. Communication between tourism service providers and users thereof must be constant and intense in order to develop trust and loyalty of consumers towards the tourist business. Modern company involved in the tourism industry corresponds to these requirements by combining all available resources through innovation and application of modern technologies of electronic commerce (Buhalis, 1998). This situation leads to the necessity of e-tourism which according to him represents "the application of modern information - communication technologies in the tourism industry" (Buhalis, 2003). Buhalis further define that tourism is an electronic digitization of business processes and value chains in tourism, travel, hospitality and catering industry (Buhalis, 2003). Furthermore, electronic tourism, observed from strategic level, can lead to entire business processes revolution, supply chains and strategic relationships tourism organizations with all interested parties. The same author points out that electronic business in tourism can also be used on tactical level in order to increase the efficiency and effectiveness of companies in the tourism industry (Buhalis, 2003). Other authors define electronic tourism is defined by some other authors as the "digitization of all processes and value chains in the tourism and hotel industry, which enables tourism businesses to maximize their efficiency, effectiveness and ease of communication with consumers" (Page and Connell, 2009).

It is certain that the yachting industry is certainly under heavy influence of Internet and e-business Luxury yachting is an very complex international industry which consists of many different stakeholders such as manufacturers of yachts, yacht designers, marinas, ports, yachting agencies, brokers, freight forwarders, customs and others, organization, human resource management. All these participants have the constant necessity of performing of supply and demand trends analysis of the global yachting market, in order to maintain the quality, efficiency and effectiveness of operations, services and products. Furthermore, in order to align strategic planning processes with business strategy formulation and business goals definition. In addition, the marinas as central elements of yachting industry have to organize all their operational and marketing activities and to include appropriate business models so that they can attract tourist's boaters and other users of their products and services. Internet and electronic business in the yachting industry enables easier implementation of all those processes and activities. The application of the Internet and electronic business, for all participants of yachting industry represents the possibility of business network creation for mutual cooperation between all aforementioned parties. In 
that context author Radisic suggests that in nautical tourism all marketing activities should be moderate on offer, by including the promotion of nautical tourism services in the tourism market, and attracting greater number of tourists - boaters in place and offers facilities, in order to achieve the greatest possible profit in nautical tourism that are offered (Radišić, 2009).

The impact of Internet and modern information-communication technologies, on the world tourism industry in the future, according to the author Buhalis, will be in the areas of strategic management and marketing of tourism organizations. Information-communication technologies that will lead to the transformation of the strategic position of tourist organizations in a way that will increase and change their efficiency, effectiveness, layering leads, reduce operational costs and time responding to customer requirements (Buhalis, 1998). However, Internet provides global visibility all tourist destinations in the world and connects all parts of the global tourism market (Werthner and Klein, 1999). Additionally, most authors agree that the Internet in the tourism business affected by the changed method of management of tourist enterprises. According to authors Prideaux and Carson the influence is especially noticeable in the area of collecting, processing, storage, dispersion, and information management (Prideaux and Carson, 2011). Analyzing their definition of e-business the organizational structure of the elements within the yachting industry, it can be pointed out that main reasons for introduction and electronic commerce use in nautical tourism, is nautical - tourist companies resource optimization. Also, market and competitive advantage position improvement.
As previously stated, yachting industry is a combination of tourism and maritime services sector, which offer a variety of tourist - maritime services and is the perfect environment for the implementation of e-business. The development and application of electronic commerce within the nautical - tourist industry increase the business opportunities and possibilities, as well as to the creation of new products and services. It brings together all those businesses and jobs that have direct or indirect links with the ports of nautical tourism - marinas. Precisely, the application of electronic commerce and the Internet, help to reach connection by creating a significant competitive advantage in their daily operations. Growth and development of the Internet, has a direct impact on changes in both: tourist offer and demand, at the global level. Creating new and changing (or eliminating) classic communicative and distribution channels, opening up new opportunities for both tourists and boaters for a variety of nautical - tourist company. The introduction of new, different, flexible ways of doing business, a large number of small and medium company in the field of yachting, they are able to quickly and easily enter the world market and offers its nautical - tourist services. The literature presents only a small number of few scientific papers studding the possibilities of electronic business in nautical tourist, especially the yachting industry, so this theme is very interesting and present the challenge to scientific and researches.

The available relevant literature sources point that Internet and electronic business has positive implications on tourism industry. Many empirical studies from different countries, however, have examined ICT impact and its determinants based on firm-level data in the transport and logistics 
sector. However, the majority of the studies were mainly focused on technological role of Internet and e-business in different economic organizations or on determination the factors that contributed to greater application. Hence, there is a literature gap on comprehensive research that analyzes the e-business application level in shipping organization and, especially marinas as ports nautical. In that sense, this study represents a unique research on the of Internet and e-business level of adoption in marinas of yachting industry in Montenegro. The next section presents a conceptual model used to support the data collection and analysis methods employed by the current study.

\section{Methodology}

Empirical research was conducted using a questionnaire as a basic research instrument with a sample of 200 employees in five largest marinas of Montenegro. The total number of valid respondents to questionnaire is 150 . Respondents belonging to different sectors in marinas such as: managing sector, the financial sector, the marketing, the logistics sector, the sector of law and jurisprudence, ICT sector, operative sector and security and safety sector in marinas. The aforementioned sample included all essential functional elements of business organization and structure of marinas, which also form the basis of the yachting industry in Montenegro. The questionnaire consisted of 20 questions pertaining to the examination of ways and levels of use of the Internet and e-business in their daily business activities of marinas in Montenegro. The questionnaire was composed in a way that all the questions had multiple choice answers within which respondents could check the response that best suit them. In addition to these issues, the survey contained questions with scale assessments and questions where respondents could select more than one answer, depending on the type of electronic services that are used in everyday business. When compiling the questionnaire, special attention was paid to the form of questionnaire, in order to cover all the areas of research and to simplify the answering process in order get as much real data as possible. Questions were grouped into four logical categories, in order to obtain more realistic picture of electronic business adoption level in Montenegrin marinas. Collected data analysis was made using techniques of descriptive statistics in the context of a software package for statistical data analysis in the social sciences (SPSS). The conclusions techniques were used for statistical analysis: counting, recording and evaluation.

\section{Results}

The results show that total number of computers used in different business sectors of Montenegrin marinas varies from 11 and 20 computers. All respondents in Montenegrin marinas use computers for their business activities. $44 \%$ of them count from 1 to 10 computers in the marina sector in which they are employed, $21.3 \%$ of them use 11 to 20 computers, $21.3 \%$ of respondents use 21 to 50 computers, while only $13.3 \%$ respondents have 51 or more computers in their business sectors. Analysis of this answer in interesting and it gives very high ratio between the number of employees and the number of computers applied in business marinas. Regarding Internet access and usage, all surveyed respondents answered positively. Four of five Montenegrin marinas uses ADSL Internet connection, while cable Internet and broadband Internet uses only one marina. As expected, these shown results confirmed that majority of 
different sectors in Montenegrin marinas uses low cost ADSL Internet connections, in consideration of high broadband Internet prices in Montenegro.

We believe that in connection with previously mentioned, it is necessary to incite the results from Official Statistical Department of Montenegro (MONSTAT, 2015). Data from their report shows that even $94.3 \%$ of the surveyed business companies in Montenegro use computers for daily operations. The study points that $99.0 \%$ of marinas use PC with Internet access. Compared to 2014 there was an evident growth of application of e-business in all business sectors. Internet access by DSL or another type of fixed broadband Internet connections use $97.4 \%$. The national survey also shows that $46.1 \%$ of the Montenegrin business sector companies benefit from Internet access, with a top speed at least $2 \mathrm{Mbit} / \mathrm{s}$. Furthermore, $26.9 \%$ of Montenegrin business companies have the Internet connection with speed less than $10 \mathrm{Mbit} / \mathrm{s}$, while only a small number of them, $14.0 \%$ have the Internet speed from 30Mbit/s to $100 \mathrm{Mbit} / \mathrm{s}$ (MONSTAT, 2015). Foregoing data indicate that the Montenegro business sector, generally, has positive attitude on computers and Internet use. However, the same research shows some limitations when applying modern Internet technologies such as: FTTX, WiMAX, CDS and other (MONSTAT, 2015).

In this context, Strategy for Information Society Development in Montenegro from 2012 to 2016, points out the two main reasons for these Internet adoption limits. First, lack of education and understanding the advantages of Internet business application possibilities, as a lack of digital literacy. Second, relatively high Internet access costs together with costly network equipment (Ministry for Information Society and Telecommunications, 2012). Another research states out that main preconditions for greater Internet use are: development and availability of telecommunications infrastructure and lower cost access to services. Montenegro does not have a telecommunications structure that meets the highest European standards in nautical tourism, similarly to other Mediterranean countries (Montenegro Chamber of Commerce, 2015).

The results shown in Fig. 1 indicate that the most important Internet supported business activities, in different marina sectors are: checking e-mail and exchange of electronic documents, in the first and second place. The third way the Internet is being used, is for internal communication purposes, and communications with business partners.

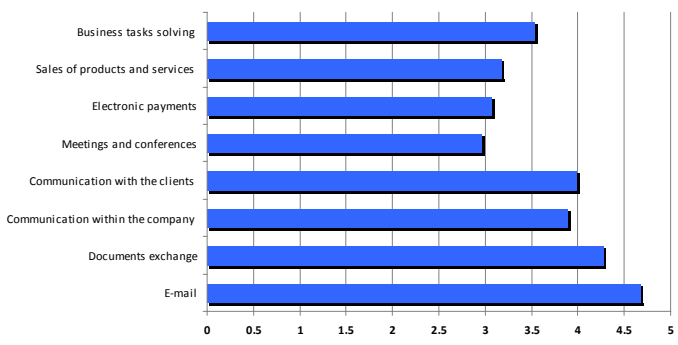

Fig. 1.

Use of the Internet for Various Business Activities in the Marinas 
Only in fifth place, the Internet is being used for direct communication with customers. Data presented in Fig. 1 shows that most of the sectors within the marinas use Internet as main communication channel, but do not use all the benefits of digital communication. Specifically, Internet is being used for electronic meetings and conferences at a very low level (14.37\%). Thus, obtained result seems to suggest that the majority of business activity carried out within the marinas do not require any special form of digital communication. Accordingly, we conclude that the Internet is still to benefit sufficiently when it comes to sale of nautical products and services that marinas offer. Furthermore, almost all respondents (97\%) indicated that basic use of Internet services - is in searching information on Internet. $95 \%$ of responders use Internet for e-mail, and Internet service in the daily operations within their business tasks. As shown in Fig. 2 the least used (3\%) Internet service is Telnet service, which actually represents remote computer usage.

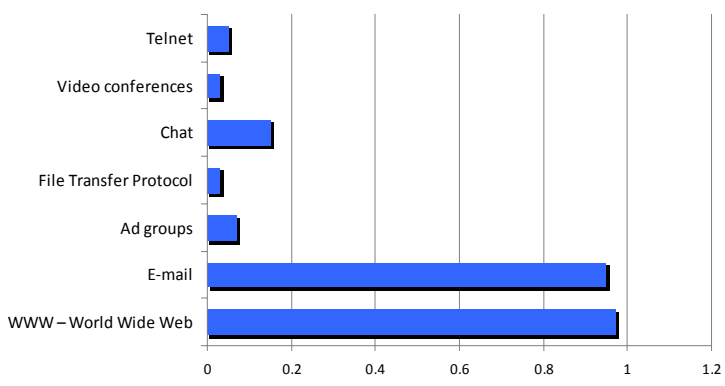

Fig. 2.

Basic Internet Services Usage in the Marinas

It has been found that one of least daily used services (3\%) is FTP (File Transfer Protocol). In addition, use of video conferencing (5\%), and Ad groups (7\%) are very poorly used. Also, IRC (Internet Relay Chat) as one of the basic services of the Internet (15\%) is not been used very often for business purposes. It would appear from data shown in Fig. 2 that certain Internet services, which in the past were much more present in modern business (Telnet, FTP) is slowly replaced with other, more sophisticated services (WWW). In addition, an interesting analysis of the application of the basic Internet services by sectors within the marina. It has been concluded that some marina sectors increasingly use some Internet services more than others. According to analyzed data, management and technical sectors most used ad groups (25\% of respondents from the sector leadership responded to use, while respondents from other sectors are generally told not to use the Internet service). Financial sector jobs in Montenegrin marinas most used FTP Internet protocol for file transfers ( $31 \%$ of respondents from the sector management responded that using FTP, while respondents from other sectors largely responded not to use the Internet service). Department of Legal Affairs of the most used Internet Telnet service (57\% of respondents from the sector management said they use the Internet service, while respondents from other sectors generally say that it is not used in everyday business). Also interesting is the fact that the sale and 
marketing most used video conferencing as one of the basic services of the Internet $(26 \%$ of respondents from the sector leadership responded to use video conferencing, while respondents from other sectors are generally told not to use).

Almost all marinas in Montenegro (98\%) own a website and have on-line presence. According to the most literary sources, having a strong online presence is a crucial component of digital marketing strategy. Since modern websites are considered basic forms of Internet advertising, it can be concluded that all Montenegrin marinas are aware of the online presence necessity and digital marketing importance. Intranet has been used at relatively high level (75\%). That is, most of employees responded that in their sector has an internal computer network that has been used in everyday business activities. It is believed that such situation, can be a result of high communication level between employees in various marina sectors. It further indicates that the observed marinas probably have a database where employees through Intranet, are able to access accurate and reliable business information. Such information access increases the productivity of marinas business activities.

Main focus of Management Information Systems is use of modern Information and Communication Technologies in managing organizations. In the 21 st century all business organizations in different economic sectors use Information and Communication Technologies, and more recently different e-commerce systems to efficiently manage their business operations. In order to remain competitive, business companies must investigate different modern information systems such Enterprise Resource Planning or Content Management System. In that way they can leverage modern information and communication technologies capabilities and obtain global competitiveness. When it comes to the different business sectors of Montenegrin marina, modern information systems are used to help managers make better decisions, facilitate seamless internal and external communications with their employees, customers, partners or stakeholders.

The findings indicate that half of Montenegrin marinas are using business information systems (51\%), followed by electronic systems for Customer Relationship Management (33\%). Thereafter, thirdly, systems for Electronic Document Management (26\%) are used and least used system (17\%) is electronic Supply Chain Management systems, as can be seen in Fig. 3.

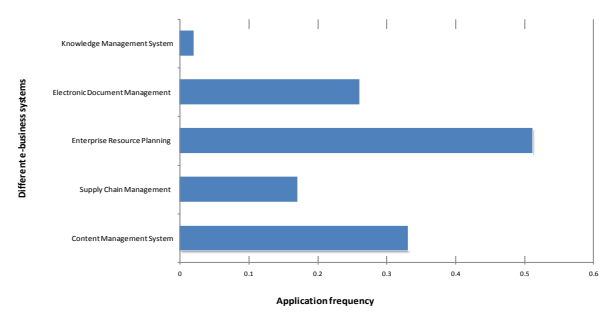

Fig. 3.

The Frequency of Different E-Business Applications Use in Montenegrin Marinas 
Different systems of electronic commerce that have found application in operating activities marina, indicates that marina management increasingly recognized the benefits of their application when the efficient and effective management of the marinas in question. As can clearly be seen in Fig. 3, business information systems occupy a central position in relation to all other e-business applications. It is noteworthy that some of the above applications are rarely used, such as for example electronic systems of supply chain management and knowledge management systems.

Interesting are the official data obtained from the Statistical Office of Montenegro, regarding the application of ERP and CRM systems in Montenegrin companies. Most companies do not use any of these systems, i.e., only $43.8 \%$ of companies in 2015 was used by ERP systems (ERP system consists of one or more software applications that integrate information and processes across the several business functions of the company) while $37.7 \%$ was used in its business CRM systems (CRM refers to the use of information technologies to collect, integrate, process and analyze information related to the client and puts consumers at the center of its activities). According to the above results of the Statistical Office of Montenegro, and the results of the investigation, an important indicator is the low level of implementation of an electronic system for managing relationships with customers in the marinas. We believe that CRM systems are most applicable when aligning business system strategy with potential client's requests. They represent a set of tools that puts at the center of business clients and is used for learning in their needs and behavior. It is from the above, we can conclude that the majority of Montenegrin marina not recognized the importance of developing long-term relationships with customers and marketing communications, nor online marketing activities for developing a strong customer relationship. The low acceptance level seems to suggest, that the marina's management level may find these technologies rather difficult to use or implement. When compared with the previous mentioned results regarding WWW or e-mail usage level, it can be concluded that complex technologies are not very used, presumably due to their high implementation costs.

When it comes to different payment systems for service charging available in Montenegrin marinas, from the results shown in Fig. 4 it is clear that the majority of financial transactions in the business of modern marina ( $82 \%)$ are still performed in traditional ways (by payment to the account). As second bidding service stands out credit card $(73 \%)$, while the third (68\%) is cash payment. Only on the fourth, fifth and sixth place are electronic banking services (57\%), payment of mobile phone (2\%) and electronic wallet payment system (1\%). More different sources indicate that electronic card payments are one of the most common payment methods in the modern business world. 


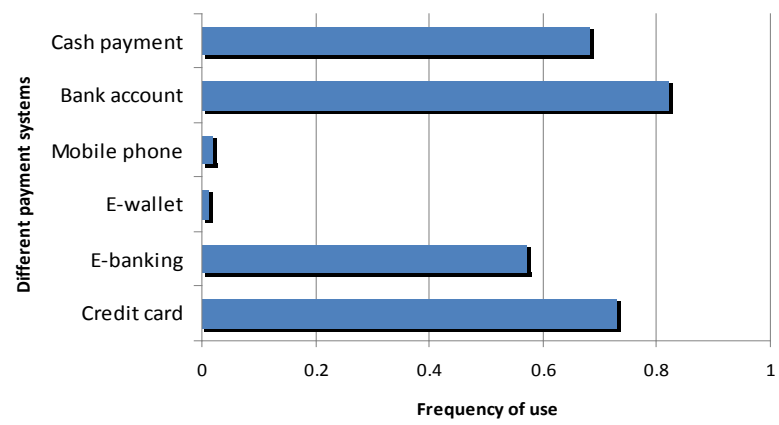

Fig. 4.

Application Frequency of Different Payment Systems in Montenegrin Marinas

Data shown in Fig. 4 show that main electronic payments forms very are very poorly used, especially when it comes to paying for mobile devices, and mobile banking. These results are surprising, since mobile banking is a modern trend in the world in the field of electronic banking. This means the ability to pay or purchase through mobile devices such as mobile phones or different tablet devices. Also surprising is the fact that in Montenegro, according to official data of the Statistical Office of Montenegro, the penetration of mobile telephony in Montenegro in June 2015 was significant $163 \%$, according to the survey mentioned by $95 \%$ of citizens in that period owned a mobile phone, that is, according to the same source, in 2015 there were 1,009,087 users of mobile telephony (MONSTAT, 2015). In view of these facts, we believe that the main reason for low application of mobile banking lack of appropriate legislation in Montenegro, when it comes to the different systems of electronic banking and the lack of safety and security. Also, possible non-compliance with the banking sector in Montenegro.
Social media is an important part of your online presence that improves your chances of generating additional revenue and building customer loyalty. It allows customers, potential customers and other interested parties to engage easily via a channel that plays an important role in their everyday lives.

Part of the research was associated with possibility of social network application in marinas business activities. It was investigated whether employees in Montenegrin marinas in their line of work use social networks such as: Facebook, Instagram, Twitter, Google+, Linkedin, Youtube and the business possibilities that they have to offer.

The results shown in Fig. 5 clearly indicate that employees in Montenegrin marinas mostly use Facebook (32\%) than Google+ service $(30,5 \%)$, thirdly Youtube (28\%) and Linkedin (26,7\%). Utilization of Instagram $(25,5 \%)$ and Twitter $(21,7 \%)$ as social media services is relatively poor. 


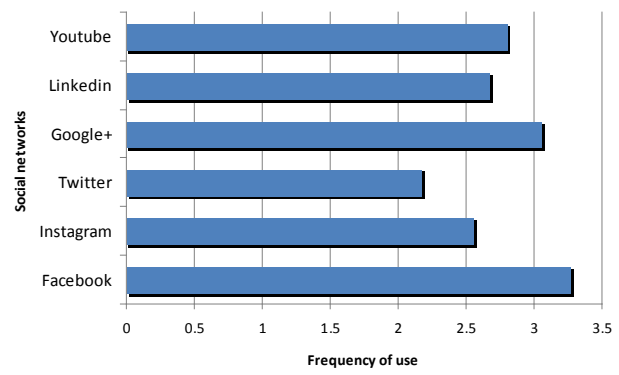

Fig. 5.

Basic Internet Services Usage in the Marinas

When data presented in Fig. 5 have been compared to survey results of the Statistical Office of Montenegro for 2015, which stated that companies in Montenegro that use social media most used social networks (43.2\%), and Web sites to exchange multimedia content $(29.2 \%)$ then the reasons for social networks application in marketing activities of Montenegrin marina were clearer. Modern nautical tourism business shows that there is a clear trend of social media application particularly in the areas of marketing and promotion. Although the level of social networks use in Montenegrin business sector is at relatively low level (29.2\%), the obtained results shows difference when it comes to marinas business activities. Based on the results shown in Fig. 6 it can be noted that there is a high level of knowledge about social media possibilities as marketing tool.

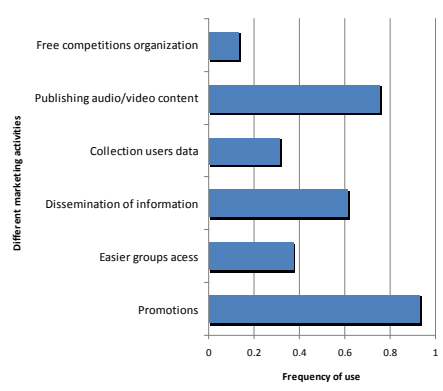

Fig. 6.

Social Networks Use for Different Marketing Activities of Montenegrin Marina

Most respondents indicated that social networks most used for purposes of promotion of free enterprise and marine (93\%), then, for the placement of advertising audio and video content marina (75\%), as a third reason for using social networking respondents said promptly informed about the news in the company (61\%), followed by the fourth, easier access to a wide variety of (interest) groups (37\%), and finally to gather information about the wishes and needs of customers (31\%) and the organization of competition (13\%). It is clear that as the basic elements of the marine yachting 
industry are business systems whose main objective is to sell nautical - tourist products and services in order to achieve the highest possible profit. These data indicate that in the management of the marina there is a clear understanding of the basic objectives of digital marketing, i.e., market research and construction (digital) brand and build strong communication links with customers and users of their services.

Employees in Montenegrin marinas recognize the importance of social networks as the main marketing tools in everyday business. That is, whether employed in marinas familiar with the possibilities offered by social networks. Comparative analysis of data shown in Fig. 5 and Fig. 6 has shown that the most used social tool for promotional marketing activities is Facebook and Youtube. This result was also expected because Facebook today currently represents number one social network, with the largest number of users.
When structure of other social networks activities was examined it was concluded that informational use of social media was in third place. Collecting data on existing and potential customers was only in fifth place. From shown results, it is evident that observed marinas recognize the social networks importance, and that there are certain activities when it comes to the application of digital marketing tools to promote the marina as well as business systems and tourist destinations, more broadly. However, from the above presented data, we may conclude that understanding of social media opportunities is still unclear when it comes to collecting customer's data in function of marina digital marketing strategy. One potential reason for this situation could be a lack in organizing regular training of employees in ICT and e-business use and application. Results indicate that employees training in most Montenegrin marinas is held two-three times a year on an average level as shown on Fig. 7.
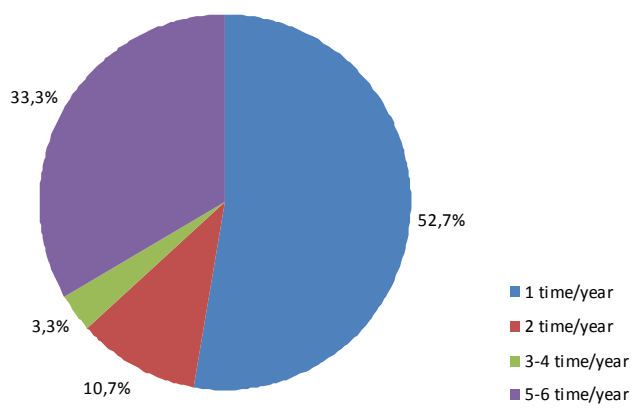

Fig. 7.

Frequency of Employees E-Business Training in Montenegrin Marinas

However, notable research into ICT field shows that modern rules of doing business forces companies to organize regular training for their human resources in modern technology use. According to various sources, most executive managers pay attention only to the technical training for the implementation of ICT in business. 
However, we believe that employees in different business sectors of Montenegrin marinas must have a wider knowledge in the field of maritime affairs and tourism. But also possess a high degree of computer literacy due to the increasing application of electronic commerce and the Internet in daily business activities. Nonetheless, we believe that employee's education in the fields of ICT, will be a key issue in the future, for problem of achieving competitive advantage on global market.

Electronic business, as previously stated, is a modern form of company's overall business activity organization. The use of ICTs and Internet represent the way for modern business organizations to adapt to volatile and ever changing business environment and to achieve greater profit. In this research we also investigated the e-business implementation level in different business sectors of Montenegrin marinas during last five years. The results obtained from the respondents regarding the level of e-business usage for the period of past five years are shown in Table 1. The e-business in 2010 was barely used (17.5\%), while in 2015 the usage level raised significantly (62.5\%). This significant difference of usage level indicates that during the period of five years managers in most of Montenegrin marina recognized e-business different application possibilities.

Data shown in Table 1 represents summary data of e-business implementation and application in all sectors of the Montenegrin marinas for the reference period (five years). Base of them, empirical evidence of an increase from $42.3 \%$ in 2011 to $76.7 \%$ in 2015 is shown.

\section{Table 1}

Electronic Business Application in the Different Sectors of Montenegrin Marinas from 2011 to 2015

\begin{tabular}{|l|l|l|l|l|l|}
\hline Use of e-business & N & Min & Max & Mean & Standard deviation \\
\hline 2011 & 12 & 1 & 5 & 1,75 & 1,288 \\
\hline 2012 & 12 & 1 & 5 & 1,75 & 1,288 \\
\hline 2013 & 12 & 1 & 5 & 2,33 & 1,497 \\
\hline 2014 & 12 & 1 & 8 & 5,83 & 2,250 \\
\hline 2015 & 12 & 3 & 8 & 6,25 & 1,765 \\
\hline $\begin{array}{l}\text { Number of valid } \\
\text { observations }\end{array}$ & 12 & & & & \\
\hline
\end{tabular}

According to presented results, it can be concluded that all business sectors in Montenegro marinas, recognized the importance of electronic business, during the implementation of their daily business activities. Use of e-business has increased more than $50 \%$ within five years. If this trend continues in the future, we can expect that e-business will be implemented in all sectors of marinas of Montenegro. E-commerce in marinas of Montenegro can be seen as chance and the tools necessary to carry out the optimization of all its business activities, organizational structure, reducing total operating costs and better positioning on the yachting market. 


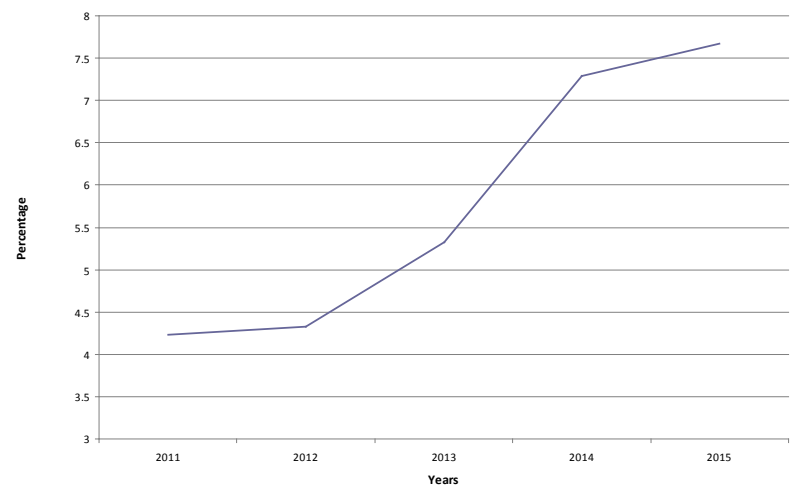

Fig. 8.

The E-Business Application Level in Montenegrin Marinas from 2010 - 2015

Summary data presented in Fig. 8 clearly shows that the e-business application level in Montenegrin marinas for past five years is rising constantly. According to the data shown, it can be concluded that the application of electronic business in 2011 amounted to $42.3 \%$, while in 2015 amounted to $76.7 \%$, that is, e-business implementation degree has risen almost twice in five year period. According to presented data, highest growth of electronic business application was realized in the period from year 2012 to year 2014. Furthermore, a detailed data analysis confirmed that the most of analyzed marinas are relatively young business organizations, even if there are differences in terms of ownership structure. Results also demonstrated that the majority of Montenegrin marinas have e-business development strategy (62\%). All of these findings suggest that such drastic increase of e-business adoption can be attributed to the fact that most of the marina only began with the e-business application, but on a very high level.

\section{Summary and Conclusions}

The results shown in this paper clearly indicate that the Internet and e-business application level in Montenegrin marinas of nautical tourism is low, but with growth tendency. Nevertheless, it seems that there is a constant need for e-business application regardless the type or size of the marina. The highest level of e-business implementation has been detected in marketing and financial sectors, which was expected given the nature of the business activities carried out by the marinas. Modern marinas have constant necessity for new markets penetration and continual communication with their customers and business partners. Also, increasing e-business application need is present in safety and security sectors in the marinas. Over five year period, e-business application increased from $17.5 \%$ to $62.5 \%$. It is important to notice that such percentage growth indicates that application of different e-business techniques has been recognized by Montenegrin marinas management. 
However, as the development level of yachting industry in Montenegro is still not satisfactory, we can conclude that the overall level of e-business adoption in nautical - tourism industry is still far from desirable. That on the managerial level of Montenegrin marinas recognize the importance of e-business inclusion importance is recognized. The results have confirmed that different electronic business techniques are applied in the different sectors within main Montenegrin marinas. The degree of e-business adoption depends on the type of sector or type of business. However, the above results indicate that there are certain restrictions to increase electronic business implementation. We believe that the main reasons could be: low level of investments in information communication infrastructure, insufficiently clear vision of management structures in the marinas, and the importance given to the infrastructure as a basis of application of information technology. That straightened high costs of introducing new technical and technological solutions, is the main obstacle to increasing the level of use of electronic business in the Montenegrin marinas, and probably the lack of qualified staff with suitable IT knowledge and skills.

We believe that the importance of e-business application of yachting industry, in the future, will continue to grow and will become crucial in the creation of new nautical products and services. The modern marina cannot maintain a high competitiveness level if their business activities rely heavily on Internet and e-business tools. In order to increase the level of Internet and e-business adoption in Montenegrin marinas, it is necessary to increase investment in ICT, as base of electronic business. Consequently, it is necessary to complete the construction of new marinas in Montenegro, in which way a quality nautical infrastructure will be obtained. Correspond to the requests of modern nautical tourist needs. Without clear ideas, knowledge and e-business development strategy, consistent with main business strategy, it is not possible to answer to the high standards and growing demands on both the domestic and international yachting market.

\section{Limitation and Further Research}

This empirical study has determined Internet and e-business application level in main Montenegrin marinas of nautical tourism. One limitation of this study is that only marinas as main objects of yachting industry have been analyzed. Further studies can be directed toward analyzing e-business adoption of other different yachting industry elements. In addition, determining barriers of e-business adoption may be considered.

\section{References}

Buhalis, D. 1996. Information technology as a strategic tool for tourism, Tourism Review, 17(2): 34-36.

Buhalis, D. 1998. Strategic use of Information technologies in the tourism industry, Tourism Management, 19(5): 409-421.

Buhalis, D. 2003. eTourism: Information Technology for Strategic Tourism Management, Prentice Hall, Pearson. London. $21 \mathrm{p}$.

Dourmas, G.; Nikitakos, N. 2009. A new approach to the digital maritime economy. In Proceedings of the European and Mediterranean Conference on Information Systems (EMCIS2009).

Dulčić, A. 2002. Nautical tourism and nautical tourism port management, Ekokon. Split. 9 p. 
Hjalager, A. 2010. A review of innovation research in tourism, Tourism Management, 31(1): 1-12.

Internet Live Statistics. 2016. Available from Internet: <http://www.internetlivestats.com/internet-usersby-country $>$.

Kesar, O. 2013. Nautical Tourism, Economic Faculty. University in Zagreb. Zagreb. 12 p.

Krmac, E. 2007. Interdependence between Logistics Activities and Information Communication Technologies (ICT), PROMET - Traffic\& Transportation, 19(2): 115-119.

Luković, T. 2007. Nautical Tourism, University of Dubrovnik. Dubrovnik. 30 p.

Luković, T.; Šamanović, J. 2006. Management and Business Economics in nautical tourism, Croatian Hydrographic Institute. Split. 20 p.

Ministry for Information Society and Telecommunications. 2012. Strategy for the development of Information Society 2012-2016, Podgorica. 10 p.

Ministry of Tourism and Environment of Montenegro. 2008. Montenegro tourism development strategy to 2020, Podgorica. 20 p.

MONSTAT. 2015. ICT usage in enterprises in Montenegro in 2015. Available from Internet: <http:// www.monstat.org/userfiles/file/ICT/2015/>.

Montenegrin Ministry of Finance. 2015. Annual Report. Available from Internet: <http://mep.c-g.me/godisnjiizvjestaj-ministarstva-finansija-cg-2015/>.

Montenegro Chamber of Commerce. 2015. IT sector in Montenegro. Available from Internet: <http://www. privrednakomora.me/en/multimedija/publikacije/ it-sektor-u-crnoj-gori>.
Nikitakos, N.; Lambrou, M. 2007. Digital shipping: The Greek Experience, Research in Transportation Economics, 21: 383-417.

Page, S.; Connell, J. 2009. Tourism: A Modern Synthesis, Third Edition. Cengage Learning. Hampshire. 12 p.

Prideaux, B.; Carson, D. 2011. Drive Tourism Trends and emerging markets, Routledge. New York. 112 p.

Radišić, B. 2009. Marketing of destination tourist product, Opatija, Faculty for management in tourism and hospitality. Opatija. $10 \mathrm{p}$.

Šamanović, J. 2002. Nautical tourism and marinas management, Maritime Faculty Split. Split. 23 p.

Sheldon, P. 1994. Information technology and computer systems, Tourism marketing and management handbook, 2nd edition. Prentice Hall. London. 34 p.

Twrdy, E.; Krmac, E. 2002. E-Commerce in Ports. Technology and Management of Traffic, PROMET Traffice Transportation, 14(1): 33-37.

Wayne, S. 1995. Tourism and technology: approaching the 21st century, WTO News, 2: 7-10.

Werthner, H.; Klein, S. 1999. ICT and the changing landscape of global tourism Distribution, Electronic Markets, 9(4): 256-268.

World Economic Forum. 2015. The Global Information Technology Report. Available from Internet: <http:// www3.weforum.org/docs/WEF_Global_IT_ Report_2015.pdf $>$. 